\title{
A new species of Crinoniscus Pérez, 1900 (Crustacea: Isopoda: Crinoniscidae) parasitising the pedunculate barnacle Heteralepas newmani Buhl-Mortensen \& Mifsud (Cirripedia: Heteralepadidae) with notes on its ecology and a review of the genus
}

\author{
Lene Buhl-Mortensen $(\mathbb{D} \cdot$ Jason D. Williams • Christopher B. Boyko
}

Received: 10 August 2019/Accepted: 12 January 2020/Published online: 17 February 2020

(C) The Author(s) 2020

\begin{abstract}
The new species Crinoniscus stroembergi n. sp. belonging to the parasitic isopod family Crinoniscidae Bonnier, 1900, is described from a pedunculate barnacle host collected in the Mediterranean Sea. This is the first species of Crinoniscus Pérez, 1900 described from a host in the genus Heteralepas Pilsbry. The male cryptoniscus larva is distinguished from congeneric species by having a dorsoventrally flattened body with the posterolateral margins of the cephalon scarcely extending beyond the anterior margin of pereomere 1 (in contrast to $C$. cephalatus Hosie, 2008 with extended margins);
\end{abstract}

This article was registered in the Official Register of Zoological Nomenclature (ZooBank) as urn:lsid:zoobank.org:pub:CD58B03F-AF61-402D-AFA7FA395D16F600. This article was published as an Online First article on the online publication date shown on this page. The article should be cited by using the doi number. This is the Version of Record.

This article is part of the Topical Collection Arthropoda.

\section{Buhl-Mortensen ( $\square)$}

Institute of Marine Research, Bergen, Norway

e-mail: Lenebu@hi.no

\section{J. D. Williams · C. B. Boyko}

Department of Biology, Hofstra University, Hempstead,

NY, USA

\section{B. Boyko}

Division of Invertebrate Zoology, American Museum of

Natural History, New York, NY, USA articles 1 and 2 of the antennule being subequal in width and the anterodistal angle of antennule article being low and rounded; propodus of pereopods 6 and 7 having a sinuous dorsal margin that is distally narrowing and the posterior margin of the pleotelson being short and rounded. The mature females of species in Crinoniscus are of two basic forms: those with ventrolateral lobes on the pereomeres $(C$. alepadis (Gruvel, 1901) n. comb., and C. politosummus Hosie, 2008) and those lacking such lobes $(C$. cephalatus and $C$. stroembergi n. sp.). The mature females of $C$. stroembergi $\mathrm{n}$. sp. can be distinguished from other species of Crininiscus based on their lacking lobes on the anterior end. The material examined includes the male and three female developmental stages of the parasite in the host, Heteralepas newmani Buhl-Mortensen \& Mifsud. The mouthparts of the immature female are described and the feeding biology and effects on the host are discussed along with a review of feeding modes in species of the Cryptoniscoidea. Leponiscus alepadis is transferred to Crinoniscus; the latter genus now contains five species. A modified diagnosis of Crinoniscus is provided. 


\section{Introduction}

Cryptoniscoidea Kossmann, 1880 contains nine families of endo- and ectoparasitic epicaridean isopod species associated with a diverse assemblage of crustacean hosts (Boyko et al., 2008 onwards); species in the genus Crinoniscus Pérez, 1900 (Crinoniscidae Bonnier, 1900) specialise in parasitism of sessile and pedunculate thoracican barnacles (Hosie, 2008; Williams \& Boyko, 2012). The life-cycle of epicaridean isopods typically includes two hosts (e.g. Trilles, 1999; Williams \& Boyko, 2012), and the cryptoniscus larva is the stage that seeks out the definitive host. In species of the Cryptoniscoidea, an adult female develops from a cryptoniscus larva with male characters that metamorphoses in response to contact with an appropriate host, but usually only if they are the first larva to encounter that host (Caullery \& Mesnil, 1901; Caullery, 1952; Blower \& Roughgarden, 1987).

Once triggered by (presumably) environmental cue(s), the metamorphosing female dramatically transforms into an adult that retains few isopod characters and is sac-like in appearance and filled with eggs or epicaridean larvae ("environmental sex determination" sensu Subramoniam, 2017). Unusually among epicarideans, in species of Crinoniscus one or more subsequent larvae encountering a host that already is infested by a female parasite can also be triggered to develop into females as well; a single host can therefore contain several females in various stages of development. Some larvae that encounter a host already parasitised by a female (or females) do not metamorphose but retain the cryptoniscus larval appearance while the testes mature (i.e. they are neotenous). These functional males serve only to fertilise the female; they do not parasitise the host themselves. Thus, the form of hermaphroditism in cryptoniscoids is different from the typical protandric sequential hermaphroditism found in other epicarideans (e.g. Bopyridae); in cryptoniscoids, one or more larvae with incipient male characters (present but undeveloped testes) will turn into females without fertilising other females (as opposed to most bopyrids where all larvae will go through a functional male phase with fully developed testes). Subramoniam (2017) indicated that cryptoniscoids represent an example of "normal intersexuality (as part of a lifecycle)" but a more precise term for this reproductive strategy would be "conditional protandric sequential hermaphroditism" where some larvae transform from males to females without fertilizing others.

Fong et al. (2017) stated that for Hemioniscus balani Buchholz, 1866, the second cryptoniscus larva to enter a host, fertilises the female and then leaves the host but we are unaware of any published data that conclusively show males actually leaving the host in which they performed fertilisation; in fact, it is clear in Crinoniscus at least that males appear not to leave the host, given that up to six females and three males can be found in a single host. It is not clear what the cue is that switches a larva from a male to female developmental trajectory; it may be that direct contact with the host leads to the female form while direct contact of the larva on a developing female maintains the male condition and triggers further testes development but experimental studies are needed to settle this question. Bocquet-Védrine \& Bocquet (1972a) indicated that young females (herein labeled as early immature females) are already fertilised but it is unknown when fertilisation occurs (within the barnacle host or soon after settlement on barnacle prior to invasion of the host). Present knowledge on the development from the larva that encounters the host to the mature female stage is very limited for species in Crinoniscus, with the exception of studies by Bocquet-Vedrine \& Bocquet (1972a, b) on C. equitans Pérez, 1900 associated with its host, Perforatus perforatus (Bruguière).

Prior to the present study, there were three accepted species within Crinoniscus (see Hosie, 2008): Crinoniscus cephalatus Hosie, 2008, C. equitans Pérez, 1900, and C. politosummus Hosie, 2008. However, Leponiscus Giard, 1887 (containing species also found parasitising pedunculate barnacles) is not monophyletic if it contains L. anatifae Giard, 1887 and L. alepadis Gruvel, 1901, because the latter species should also be included in Crinoniscus.

Giard (1887) placed two species in Leponiscus: L. anatifae and L. pollicipedis Giard, 1887, but the latter name is a nomen nudum. Giard (1887) did not designate a type-species for Leponiscus, but only one of the originally included species is an available name, therefore L. anatifae is the type-species of Leponiscus by monotypy. Bocquet-Védrine \& Bocquet (1972c) considered L. anatifae a nomen nudum, making Leponiscus an available name from Gruvel (1901) rather than Giard (1887); this was followed by Hosie (2008). Giard (1887), however, explicitly referred to 
figures in Hesse (1867) as representing L. anatifae and L. anatifae is therefore available from Giard (1887) (ICZN, 1999, Article 12.2.5). Except for the typespecies, the only other valid taxon in Leponiscus is L. alepadis. It is clear from the illustrations of Hesse (1867), on which $L$. anatifae was based, that $L$. anatifae is close to if not identical with Hemioniscus balani (Hemioniscidae) whereas L. alepadis clearly belongs to Crinoniscidae (see Gruvel, 1901, 1902). No material from Hesse (1867), including the specimens parasitising Lepas anatifera (Linnaeus) that Giard (1887) based L. anatifae on, is known to be extant and the types of $L$. alepadis parasitising Paralepas minuta (Philippi) are not present in the Muséum national d'Histoire naturelle (MNHN). Because we lack material of either of these species, we take the conservative approach and retain Leponiscus as a valid genus within the Hemioniscidae while transferring L. alepadis to Crinoniscus. If the antennular plate of the cryptoniscus larva is as shown by Gruvel (1902: plate 1, figure 3), then L. alepadis should be placed in its own genus; however, it is equally possible that Gruvel (1901, 1902) misrepresented this structure as all the characters of the female parasite (e.g. pereon and pleon shape, lateral lobe development) strongly suggest placement within Crinoniscus, which is where we opt to place it at this time as Crinoniscus lepadis (Gruvel, 1901) n. comb.

In the present paper, we describe a new species of Crinoniscus, including a description of the developmental stages found in association with its host, a specimen of Heteralepas newmani Buhl-Mortensen \& Mifsud. In addition, we present new and detailed morphology of the female parasites together with observations on development and feeding strategy within this group of epicarideans. Species of the Cryptoniscoidea have often been presumed to be parasitic castrators of their hosts by feeding on the host hemolymph and ovarian fluid (Williams \& Boyko, 2012). Our observations, however, confirm the results of Bocquet-Vedrine \& Bocquet (1972a) for C. equitans and show that female parasites in Crinoniscus are morphologically adapted to feeding on eggs and larvae of their host, and not directly on the host itself as is often the case for other epicarideans. We discuss the morphology of cryptoniscoid late immature female mouthparts and review the feeding biology in this group, one that has been largely overlooked as egg predators.

\section{Materials and methods}

Nine parasites, including two females, four juvenile females, and three males, were found inside a single specimen of Heteralepas newmani Buhl-Mortensen \& Mifsud, collected from a nylon mooring line in the Mediterranean Sea off Malta at $35^{\circ} 51.315^{\prime} \mathrm{N}$, $14^{\circ} 11.707^{\prime} \mathrm{E}$ (host: paratype specimen $\mathrm{C}$ in the National Museum of Natural History, Mdina, Malta, collection number NMNHC040a). The line was anchored in $c .458 \mathrm{~m}$ depth, with its upper end drifting with the currents in the water column. The line became entangled with a fisherman's bottom long lines and was brought up as by-catch; the barnacles were attached at the "top" of the line, corresponding to $100-150 \mathrm{~m}$ depth. The size of the host specimen is $1.02 \mathrm{~cm}$ (combined length of capitulum and peduncle) and was listed as "specimen C" in Buhl-Mortensen \& Mifsud (2017). Isopod size is given as maximum length of females and males, anterior border of head to terminus of body (female), or uropods (larva); all measurements of parasites were made with ImageJ software calibrated with stage micrometers. Light micrographs of specimens in alcohol were created with a Macropod Pro kit (MacroscopicSolutions, Tolland, CT, USA) and the resulting pictures were aligned and stacked with the focus stacking software Zerene Stacker (10 images from bottom to top of specimens). For line drawings, drawing tube sketches of specimens were produced with Olympus dissecting and compound light microscopes and then traced with Adobe Illustrator to create final figures. For SEM preparation, specimens were dehydrated in an ascending ethanol series, starting with $70 \%$ and ending with $100 \%$ (10 min per dilution through $95 \%$ and $15 \mathrm{~min} \times 3$ for $100 \%)$. Drying of specimens was completed with a Samdri 795 Critical Point Dryer and then specimens were mounted on aluminum stubs followed by coating with gold using an EMS-550 sputter coater. Specimens prepared for SEM were examined using a FEI Quanta 250 SEM. Figures were produced using Adobe Photoshop and measurements of structures were made using ImageJ software. References are provided for authors and dates of all parasitic taxa but not for those of hosts. 
Order Isopoda Latreille, 1817

Superfamily Cryptoniscoidea Kossman, 1880

\section{Family Crinoniscidae Bonnier, 1900}

Remarks

Species in the Crinoniscidae (genera Crinoniscus Pérez, 1900 and Proteolepas Darwin, 1854) are known as parasites of sessile and pedunculate barnacles (Hosie, 2008; Williams \& Boyko, 2012). Male crinoniscids are distinguished from those of species in the Hemioniscidae by having less prominent cuticular striations, small exopods of the uropods, and lacking of posterior teeth on the antennule. During transition to adult females, crinoniscids lose all traces of the larval form, including limbs, eyes, mouthparts and segmentation (Caullery \& Mesnil, 1901; BocquetVedrine \& Bocquet, 1972a). Bocquet-Vedrine (1974, 1985, 1987) considered the Crinoniscidae to be a subfamily within the Cryptoniscidae, citing the similarities between the structures of the antennulae and in the form of the epicaridium larvae. However, because the morphology of species in BocquetVedrine's (1974) two proposed subfamilies (Cryptoniscinae and Crinoniscinae) can be readily distinguished in both larval and adult stages, the Crinoniscidae is presently retained as a family distinct from the Cryptoniscidae (Hosie, 2008). The Crinoniscidae contains two genera, Crinoniscus and Proteolepas, with six species (including the new species described herein) that appear potentially congeneric; however, the sole species in the latter genus (Proteolepas bivincta Darwin, 1854) is poorly known and recollection from the type-host Alepas cornuta Darwin (syn. Heteralepas cornuta (Darwin)) at the typelocality (St. Vincent's = Saint Vincent, Saint Vincent and the Grenadines) is necessary to determine its status. Williams \& Boyko (2012) considered $P$. bivincta a nomen dubium because of the need for a detailed redescription and knowledge of the life history. As noted by Buhl-Mortensen \& Mifsud (2017), the species described herein and P. bivincta both parasitise hosts in Heteralepas; however, a species of Scalpelloniscus Grygier, 1981 is also known to parasitise species in Heteralepas (see Hosie, 2008).

\section{Crinoniscus Pérez, 1900}

\section{Diagnosis}

Cryptoniscus body tear-drop shaped, c.2.5 times longer than wide. Cuticular striations present. Cephalon wider than long; eyes forming hyaline lens. Oral cone anteriorly directed. Antennule with three articles; first article, coxal plates and pleotelson without posterior teeth. Antenna with nine articles; four basal articles and five flagellar articles subequal in length. Pereopods 1, 2 gnathopodal, 3-7 ambulatory; dactylus of pereopods 3-5 approximately half propodus length; dactylus of pereopods 6-7 at least as long as propodus. Pleopods with two subequal rami. Pleotelson posterior margin smooth, posteriormedial lobe rounded, less than half width of entire posterior margin. Uropods biramous, exopod less than half as long as endopod. Anal tube absent. Immature female segments incompletely fused, lacking appendages except for uniarticulated antennae in some species, mandibles and elongate second pereopods. Mature female fusiform or anteriorly globose, posteriorly annulated, lacking appendages (remnants of pereopod 2 present in some species). Type-species: Crinoniscus equitans Pérez, 1900.

\section{Remarks}

The diagnosis is slightly modified from that given by Hosie (2008) for the genus to better account for the variability seen in some characters (e.g. presence of pereopod 2 remnants in mature females). Included species: Crinoniscus alepadis n. comb. (Mediterranean off France and off Western Sahara, infesting Paralepas minuta (Philippi), depth of 250-355 m); C. cephalatus Hosie, 2008 (off New Zealand, infesting Amigdoscalpellum costellatum (Withers), depth of 263-648 m); C. equitans Pérez, 1900 (North-East Atlantic off France, infesting Perforatus perforatus (Bruguière), shallow waters); C. politosummus Hosie, 2008 (off New Zealand, infesting Glyptelasma gigas (Annandale), G. gracile (Hoek) and Poecilasma kaempferi Darwin, depth of 480-730 m), and $C$. stroembergi n. sp. (off Malta, infesting Heteralepas newmani Buhl-Mortensen \& Mifsud, depth of $100-150 \mathrm{~m})$. 


\section{Crinoniscus stroembergi $\mathbf{n}$. sp.}

Syn. "Isopod parasite (Crinoniscidae)" of BuhlMortensen \& Mifsud (2017)

Type-host: Heteralepas newmani Buhl-Mortensen \& Mifsud (Cirripedia: Heteralepadidae).

Type-locality: Mediterranean Sea off Malta $\left(35^{\circ} 51.315^{\prime} \mathrm{N}, 14^{\circ} 11.707^{\prime} \mathrm{E}\right)$, depth of $100-150 \mathrm{~m}$.

Type-material: Male holotype $(1.01 \mathrm{~mm})$ (NMNHC040e), 2 male paratypes (1.06 mm, 1.14 $\mathrm{mm}), 5$ juvenile female paratypes $(1.52-5.38 \mathrm{~mm})$ (NMNHC040f), and 1 mature female allotype (4.4 $\mathrm{mm}$ ) (NMNHC040g) from Heteralepas newmani (paratype specimen C, Museum of Natural History, Mdina, Malta, collection number NMNHC040a), collected from a nylon mooring line at $100-150 \mathrm{~m}$ in the Mediterranean Sea off Malta.

ZooBank registration: To comply with the regulations set out in article 8.5 of the amended 2012 version of the International Code of Zoological Nomenclature (ICZN, 2012), details of the new species have been submitted to ZooBank. The Life Science Identifier (LSID) for Crinoniscus stroembergi $\mathrm{n}$. sp. is urn:lsid:zoobank.org:act:9257BEA3-94DF-48EB-981C-

\section{BA2540C 14158 .}

Etymology: Named in honour of the Swedish marine biologist, Jarl-Ove Stömberg, whose analysis of morphological characters that are taxonomically relevant within the Cryptoniscoidea (e.g. Nielsen \& Strömberg, 1973a, b) has greatly influenced the systematics of these parasitic isopods.

\section{Description (Figs. 1-4)}

Holotype male [NMNHC040e; Figs. 1A, 2A, 3A.] Body tear-drop shaped, total length $1.01 \mathrm{~mm}$ (length of three males ranged from 1.01 to $1.14 \mathrm{~mm}$ ), widest at pereomere $4(0.36 \mathrm{~mm})$, anterior and posterior segments tapering slightly. Median region of pereomeres 4-7 containing pair of opaque, oval-shaped testes (Figs. 1A, 3A) resembling those shown in Caullery \& Mesnil (1901: figure 2). Cuticular striations distinct on most segments and appendages but absent on cephalon and reduced dorsally on pereomeres 1 and 2; cuticular striations on ventral surface generally fringed by minute extensions or "ctenae" (see Remarks) (Fig. 2F). Anterior margin of cephalon evenly rounded with distinct rim (Figs. 1A, 3A), cephalon $0.3 \mathrm{~mm}$ in width, $0.15 \mathrm{~mm}$ in length. Eyes ovate, posterolateral, near junction with pereomere 1 (Figs. 1A, 3A); after fixation, lens tinted with yellowish pigment. Antennule of three articles (Figs. 1B, 2A, $\mathrm{B})$, cuticular striations on articles 1 and 2; article 1 margins entire, mesial margin curved, abutting opposite antennule, lateral margin concave, overlapping some of article 2, cuticular striations and 3 setae present near posterior margin (Fig. 1D) and seta near anterior point; article 2 ovate, cuticular striations and few setae near lateral margin; article 3 with bundle of long setae dorsally and seta near base of 2 rami; anterior and posterior rami with $c .3$ and $c .4$ terminal setae, respectively, posterior ramus slightly longer than anterior ramus (Figs. 1B, 2B). Antenna of 9 articles (Figs. 1C, 2A, C), reaching pereomere 6, composed of 4 peduncular articles with prominent striations and 5 flagellar articles; basis rounded anteriorly and extending mesially as rounded lobe overlapping article 2 by $c .1 / 3$ of its length; article 2 and remaining segments cylindrical, flagellar articles approximately half as wide as terminal peduncular article; all articles with at least one short distal seta prior to article joint, terminal flagellar article with two longer setae (Figs. 1C, 2A, C). Oral cone triangular, anteriorly directed (Figs. 1D, 2A, B), mandibles styliform, thin and pointed at distal end.

Pereopods 1 and 2 gnathopodal (Figs. 1E, 2A, D), dactylus short, hooked, c.1/3 of propodus length, tooth-like structures on terminus of propodus opposing dactylus tip; propodus large, egg-shaped, tapering distally; carpus triangular, tuft of fine setae at distal angle; merus subtriangular with distal seta; ischium and basis cylindrical; cuticular striations on all articles. Pereopods 3-5 ambulatory (Figs. 1F-H, 2F$\mathrm{H})$, dactylus elongate, about half propodus length; propodus distally quadrate and flattened, ventral margin somewhat concave, with robust scale near joint, single small seta present medially and ridge of ctenae from medial seta to joint with dactylus; carpus and merus triangular, each with distal seta; ischium triangular, approximately twice as large as merus; basis long, cylindrical; dactylus without cuticular striations, remaining articles with cuticular striations and ctenae. Pereopods 6 and 7 ambulatory (Figs. 1I, J, $2 \mathrm{H})$ with more slender articles than preceding pereopods, dactylus of each $1-1.25 \times$ propodus length, respectively; propodus tapering distally to rounded junction with dactylus, a single seta submedially and 


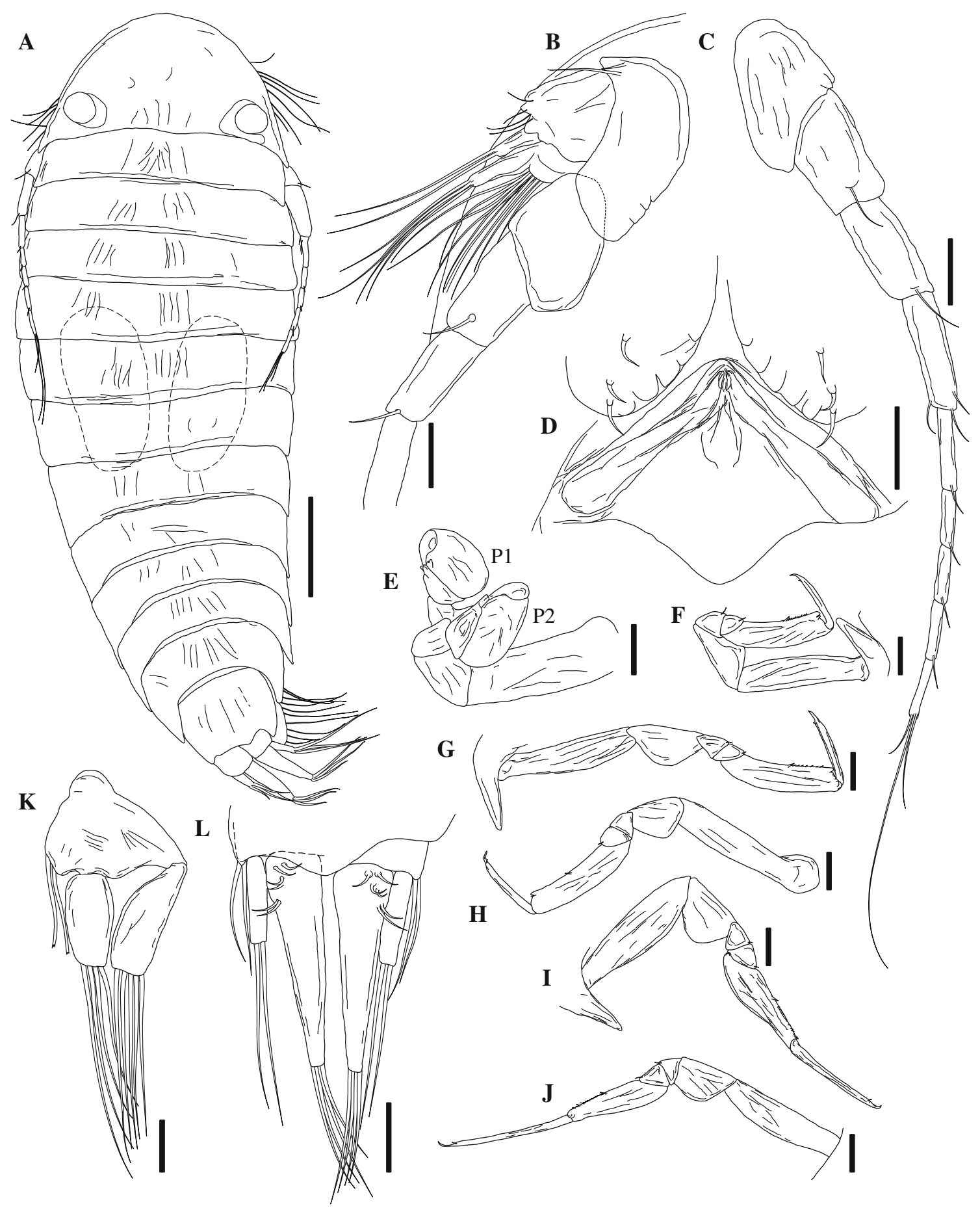

Fig. 1 Crinoniscus stroembergi n. sp. ex Heteralepas newmani (specimen C, NMNHC040a). Holotype, male (NMNHC040e) (A-C, E, H, J, K) and paratypes (NMNHC040f) (D, F, G, I, L). A, Dorsal view; B, Right antennule; C, Left antenna; D, Mouthparts and basal portion of antennulae; E, Left first (P1) and second (P2) pereopods; F, Right pereopod 3; G, Right pereopod 4; H, Left pereopod 5; I, Right pereopod 6; J, Left pereopod 7; K, Left pleopod 1; L, Pleotelson, dorsal view (inner setae of uropods not shown). Scale-bars: A, $125 \mu \mathrm{m}$; B-L, $25 \mu \mathrm{m}$ 


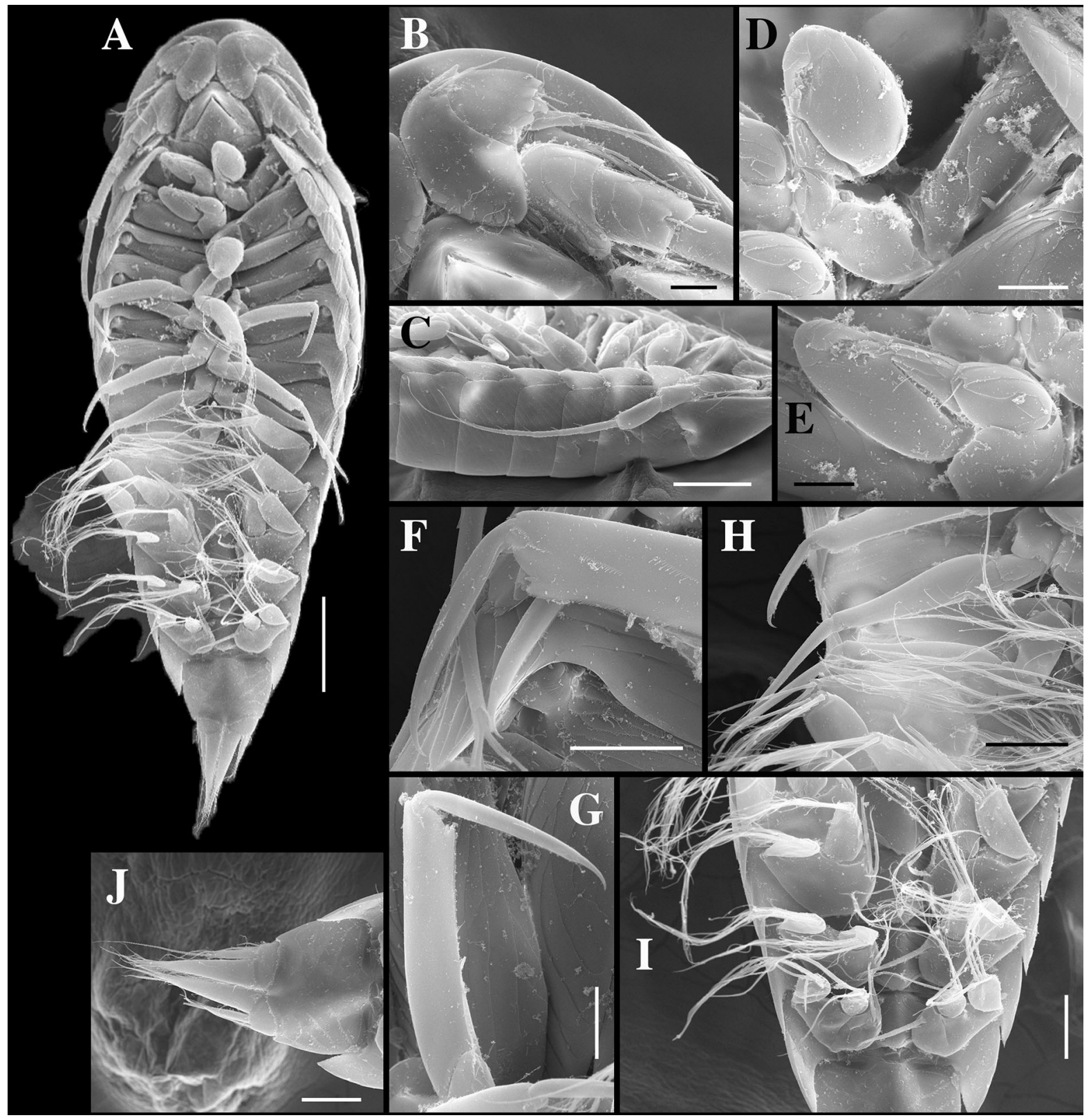

Fig. 2 Crinoniscus stroembergi n. sp. ex Heteralepas newmani (specimen C, NMNHC040a). Paratype, male (NMNHC040f). A, Ventral view; B, Left antennule; C, Left antenna; D, Left pereopod 1; E, Right pereopod 2; F, Right pereopod 3; G, Left pereopod 4; H, Right pereopods 5-7; I, Abdomen showing pleopods 3-5; J, Pleotelson, ventral view. Scale-bars: A, $125 \mu \mathrm{m}$; B, D, G, $25 \mu \mathrm{m}$; C, $100 \mu \mathrm{m}$; E, $20 \mu \mathrm{m} ; \mathrm{F}, 30 \mu \mathrm{m} ; \mathrm{H}-\mathrm{J}, 50 \mu \mathrm{m}$

supramedially on pereopod 6 and 7, respectively; merus, carpus, and ischium with cuticular striations as in pereopods 3-5. Coxal plates (Fig. 2C) without posterior teeth, those on pereomeres 1 and 2 rounded, remainder pointed, all with cuticular striations.
Pleopods (Figs. 1K, 2A, I) of five pairs, becoming progressively smaller posteriorly. Bases of pleopods 1-5 each with 2 flattened, mesially directed trifurcate setae; distal margin forming lobed lamella submedially covering bases of rami; exopod with 5 sparsely plumose setae; lateral seta approximately one-third 


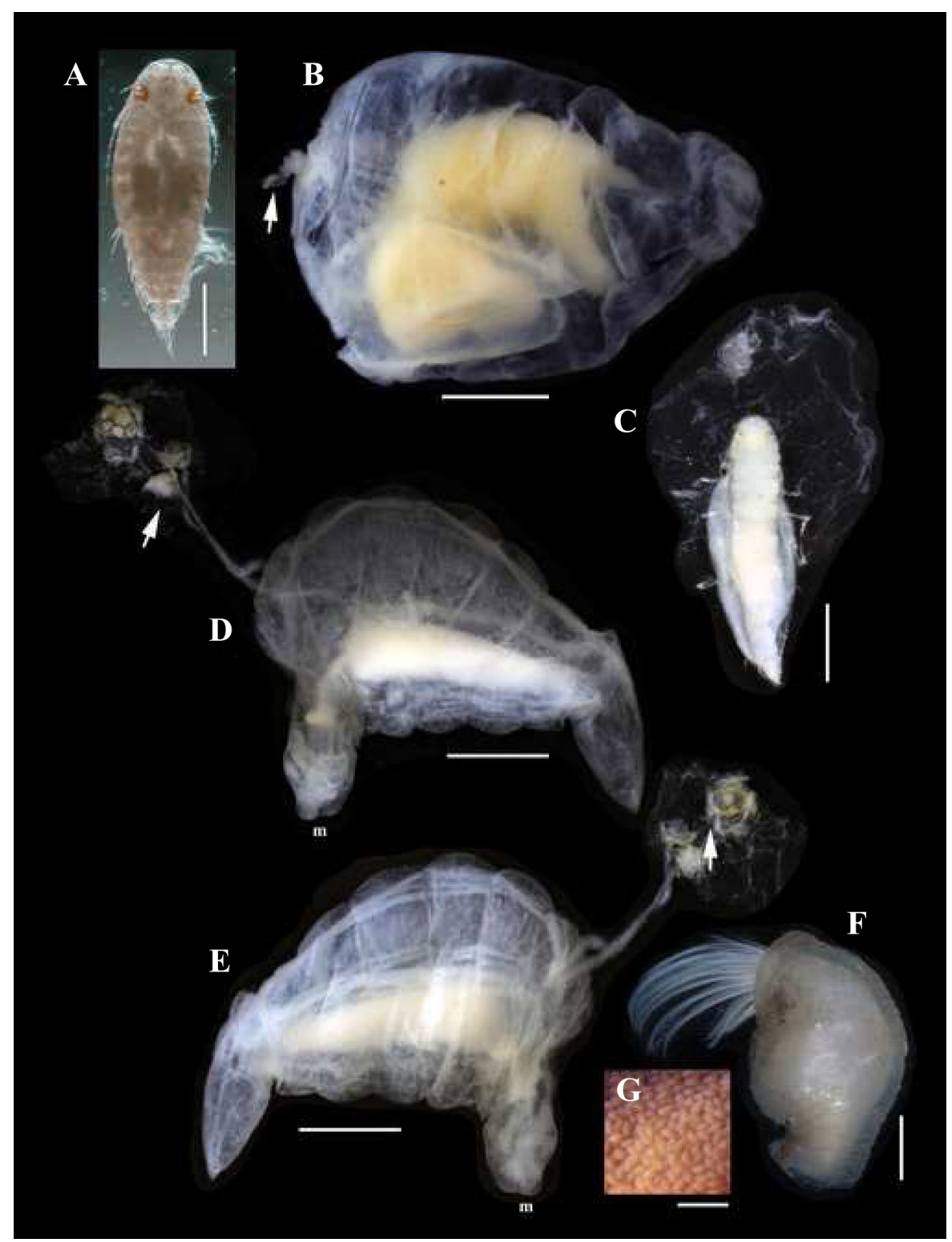

Fig. 3 Crinoniscus stroembergi n. sp. ex Heteralepas newmani (specimen C, NMNHC040a). A, Paratype male (NMNHC040f), dorsal view; B, Allotype female (NMNHC040g), lateral view, arrow shows remains of second pereopods; C, Paratype (NMNHC040f), early juvenile female, dorsal view, attached to host cuticle; D, Paratype (NMNHC040f), late immature female, left lateral view, arrow shows point of attachment of second pereopods; E, Paratype (NMNHC040f), late immature female, right lateral view, arrow shows point of attachment of second pereopods; F, Host barnacle, lateral view; G, Eggs of H. newmani (specimen RS3, NMNHC040a) (m, mouth). Scale-bars: A, F, G, $250 \mu \mathrm{m}$; B, D, E, $1 \mathrm{~mm} ; \mathrm{C}, 0.5 \mathrm{~mm}$

length of others; exopod quadrate distally, tapering in basal half; endopod ovate, with 5 (3 in pleopod 5) sparsely plumose setae; all articles with prominent cuticular striations (Figs. 1K, 2I). Ventral abdominal lobe (Fig. 1I) between pleopods apically rounded with medial notch. Pleotelson (Figs. 1L, 2J) twice as wide as long; posterior margin entire, forming blunt, narrow, nearly straight-sided lobe. Uropod basis quadrate, with 2 setae at posterolateral margin; exopod cylindrical with 2 terminal setae, $c .1 / 2$ length and $c .1 / 3$ width of endopod, endopod triangular with 4 terminal 


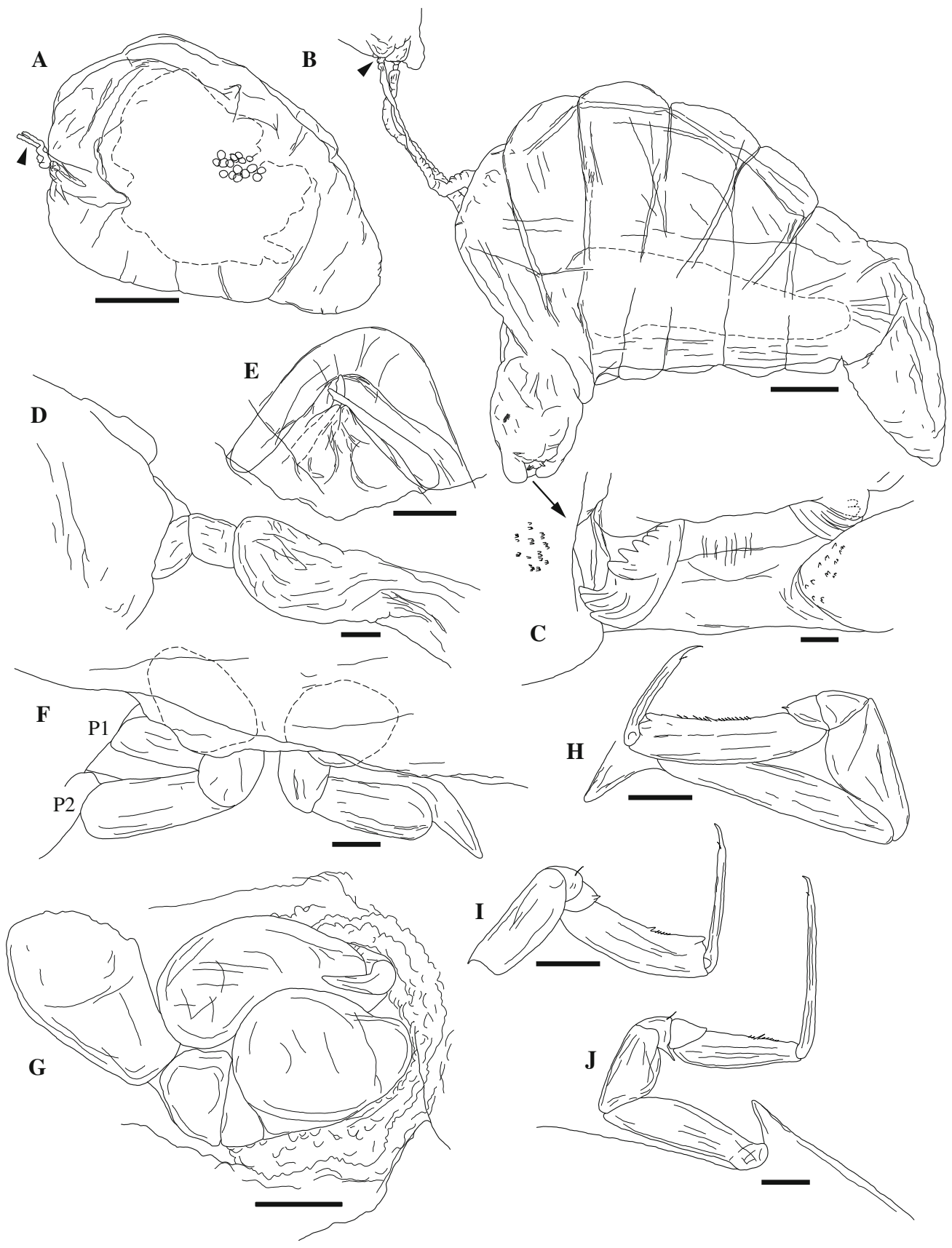

Fig. 4 Crinoniscus stroembergi n. sp. ex Heteralepas newmani (specimen C, NMNHC040a). A, Allotype (NMNHC040g). Mature female, lateral view, arrowhead shows remains of second pereopods; B, Paratype (NMNHC040f). Late immature female, lateral view, arrowhead shows long second pereopods attached to host cuticle, arrow shows position of mandibles; C, Paratype (NMNHC040f). Late immature female, close-up view of mandibles and surrounding lobes covered in scales (only some shown); D, Paratype (NMNHC040f). Late immature female, second pereopod; E, Paratype (NMNHC040f). Early immature female, mouthparts showing mandibles after compression between slides; F, Paratype (NMNHC040f). Early immature female, first (P1) and second (P2) pereopods attached to host cuticle; G. Paratype (NMNHC040f). Early immature female, left pereopod 2; H, Paratype (NMNHC040f). Early immature female, left pereopod 3; I, Paratype (NMNHC040f). Early immature female, right pereopod 4; J, Early immature female, right pereopod 7. Scalebars: A, $1 \mathrm{~mm}$; B, $0.5 \mathrm{~mm}$; C-J, $25 \mu \mathrm{m}$ 
setae, 6 small, curved setae basally on dorsal surface, mesial margin with comb of fine setae.

Allotype mature female [NMNHC040g; Figs. 3B, 4A.] Segments fused, $4.4 \mathrm{~mm}$ in total length, ovoid, with bulbous anterior end $c .2 \times$ broader than posterior, short tapering posterior end with slight indication of annulations; periphery transparent, middle of specimen with opaque egg mass; eggs $c .0 .1 \mathrm{~mm}$ diameter. Mouthparts indistinct. Proximal remnants of second pereopods present (Figs. 3B, 4A).

Late immature female [Based on one specimen (NMNHC040f); Figs. 3D, E, 4B-D.] Body length $5.4 \mathrm{~mm}$, cephalon globose, c. $1 \mathrm{~mm}$ long, 6 pereomeres, broadest across pereomere 3 , pleon short, 1.4 $\mathrm{mm}$ in length, unsegmented and tapering to point. Small patches of pigment on cephalon (eyes?) present, antennulae and antennae apparently absent. Mouth at distal end of cephalon, with multifid mandibles, 2 ridges of teeth; inner ridge smaller, with $c .6$ teeth, outer ridge with 4 stouter teeth, both curved outward (Fig. 4C); rounded extensions of cephalon extending slightly beyond mandibles, covered with very small cuticular denticules (Fig. 4C); similar in morphology to denticules of acrothoracican barnacles (see figure 6E in Williams \& Boyko, 2006). Second pereopods gnathopodal (Figs. 3D, E, 4B, E) c. $1.5 \mathrm{~mm}$ in length, with dactylus, propodus and carpus similar to those of males, deeply embedded in and surrounded by host cuticle (Fig. 4D); merus, ischium and basis fused, elongate and cord-like; other pereopods absent. Pleon (Figs. 3D, E, 4B) triangular, proximal end as wide as terminal pereomere, tapering to rounded point.

Early immature female [Based on four specimens (NMNHC040f); Figs. 3C, 4E-J.] Vermiform, c.2 mm in length (length of immature females ranged from 1.52 to $2.32 \mathrm{~mm}$ ). Body with 7 pereopods, reaching maximum width at pereomeres 5 and 6 ; body distended in middle region and containing large opaque ovary (Fig. 3C) as shown in Caullery \& Mesnil (1901; text and figure C). Cephalon anteriorly rounded, with 2 round eyes present dorsolaterally; after fixation, eye lens tinted with yellowish pigment (Fig. 3C). Pair of antennulae and antennae as in males. Oral cone (Fig. 4E) similar to that of males, mandibles styliform, slightly scalloped at distal end.
Pereopods 1 and 2 gnathopodal (Fig. 4F, G), distal ends deeply embedded in host tissue; dactylus short; propodus large, ovoid; carpus triangular; merus subtriangular; ischium and basis cylindrical. Pereopods 3-5 ambulatory (Fig. 4H, I), dactylus elongate, pereopod 3 dactylus approximately half propodus length, progressively longer in posterior pereopods; articles similar in shape and proportions to those of males. Pereopods 6 and 7 ambulatory (Fig. 4J), each with long dactylus, $1-1.25 \times$ propodus length, respectively; articles similar in shape and proportions to those of males.

Pleon with 5 segments plus pleotelson. Pleomeres slightly narrower posteriorly, distinctly separated (Fig. 3C); 5 pairs of pleopods and pleotelson as in males.

\section{Remarks}

The cryptoniscus larvae of Crinoniscus stroembergi $\mathrm{n}$. sp. can be distinguished from those of $C$. equitans in having the anterodistal angle of antennule article 1 low and rounded ( $v s$ strongly produced and triangular in $C$. equitans) and in having a sinuous and distally narrowing dorsal margin of the propodus of pereopods 6 and 7 ( $v s$ propodus dorsal margin evenly convex in C. equitans). The cryptoniscus larvae of $C$. stroembergi n. sp. can be distinguished from those of $C$. cephalatus in having the body dorsoventrally flattened (vs inflated in $C$. cephalatus), the posterolateral margins of the cephalon scarcely extending beyond the anterior margin of pereomere 1 ( $v s$ extending beyond the posterior margin of pereomere 1 in $C$. cephalatus), and in having articles 1 and 2 of the antennule subequal in width ( $v s$ article 1 twice as wide as article 2 in $C$. cephalatus). The cryptoniscus larvae of $C$. stroembergi n. sp. can be distinguished from those of $C$. politosummus in having the posterior margin of the pleotelson short and rounded, scarcely exceeding the exopod and endopod articulations with the coxopod ( $v s$ posterior margin longer and extending approximately half the length of the exopod in $C$. politosummus). The morphology and proportions of the cryptoniscus larva antennular articles in $C$. alepadis n. comb. (article 1 much narrower than article 2) are unlike those seen in any other species of Crinoniscus where article 1 is always much broader than all other articles; however, as indicated above, the depiction of the antennule may be inaccurate. 
The mature females of species in Crinoniscus are of two basic forms: those with ventrolateral lobes on the pereomere (C. alepadis n. comb. and C. politosummus) and those lacking such lobes (C. cephalatus and C. stroembergi n. sp.). Mature females of Crinoniscus stroembergi $\mathrm{n}$. sp. can be distinguished from those of C. cephalatus based on lacking lobes on the anterior end ( $v s$ lobes present in C. cephalatus) and in having less distinct segmentation of the pleon ( $v s$ segmentation more distinct in C. cephalatus).

The cuticular striations on the ventral surface and appendages of the cryptoniscus larvae are all fringed by comb-like extensions along their edges; these extensions, termed ctenae by Hosie (2008), are similar to the pectinate scales of Nielsen \& Strömberg (1973a), scales found in mature males of other epicarideans (e.g. figure 19 in Williams et al., 2019), and the combs of Klepal \& Kastner (1980: figures 23, 24). These comb-like extensions are missing on some portions of the striations but this is likely an artifact of fixation/preservation. The striations are epicuticular outgrowths (Nielsen \& Strömberg, 1973a) and the extensions are not articulated (i.e. they are not setules as defined by Watling, 1989); they appear similar in morphology to denticules or denticles (sensu Watling, 1989; Garm \& Watling, 2013, respectively).

\section{Discussion}

Metamorphosis and feeding on host eggs

The thorough description of the metamorphosis and feeding of $C$. equitans as reported by Bocquet-Vedrine \& Bocquet (1972a, b) fits in most details with our observations on the morphology of the three female stages examined for C. stroembergi n. sp. (Fig. 3). There is no indication that the mature females of $C$. stroembergi n. sp. will develop lateral lobes and the pleon does not exhibit as much distinct segmentation as seen in C. equitans.

Females in species of Crinoniscus do not feed directly on the host barnacle's hemocoel fluid as do those of species in Hemioniscus, instead the female forages on the host's eggs and/or embryos (BocquetVedrine \& Bocquet, 1972a). Eggs of the host are the main food for juvenile females and Bocquet-Vedrine \& Bocquet (1972a) observed that a cryptoniscus male attached to the egg-sac lamella of its host will (if kept in refreshed seawater) metamorphose into a young female and subsequently to a mature female. The development from male to mature female is fast (within a few days) which may explain why this metamorphosis has not been described in species of Crinoniscus with the exception of the interesting observations on $C$. equitans published by BocquetVedrine \& Bocquet (1972a, b) and a short film they made of its feeding and metamorphosis (available online at https://www.canal-u.tv/video/cerimes/ crinoniscus_equitans_perez.9107). Below we summarise the findings of Bocquet-Vedrine \& Bocquet (1972a, b).

After gaining access to the host, the cryptoniscus male clings by its pereopod 2 dactyli to the egg-sac lamella, remains still, slightly bent, and with weakened pigmentation. The process of ecdysis that leads to the young female is complex: the anterior half of the body is moulted segment by segment before the body emerges from the posterior half-exuvia, which falls off in one piece as in free-living isopods. The worm-like young female has lost its pereopods and pleopods, except for the cord-like second pereopods which are attached to the egg-sac lamella.

As soon as it is released (at least in its anterior part) from its cryptoniscus moult, the young female actively feeds on eggs or young embryos of the host barnacle (Fig. 3F, G); eggs are not taken in whole, rather their contents are drawn into the digestive tract apparently after the egg membranes are ruptured by the mandibles. The female's posterior digestive tract increases very quickly in size and is loaded with such a large mass of food reserves (yolk) that it inflates the pereon dramatically. The ingested yolk forms a yellow mass the size of a pea which makes it easy to identify a young Crinoniscus female in the host. This period of active feeding lasts from one day to a day and a half and Bocquet-Vedrine \& Bocquet (1972a, b) speculated that the long, cord-like second pereopods will, by anchoring the parasite to the marsupium, secure its position for continued egg feeding.

The increase in volume of the pereomeres, which occurs without any exuviation, causes the cord-like second pereopods to break and the female becomes free in the cavity of the host; a notable increase in length occurs simultaneously. After a few hours, the movements of the head and abdomen cease and the female becomes relatively immobile and beating of the heart is visible in the pleon. This transformation is 
also fast and lasts one day to a day and a half. In $C$. equitans, it takes 72 hours for the moulting young female to reach its mature state. It will continue to grow and two lateral lobes develop, and in several additional days spawning and embryogenesis occurs. No real exuviation interrupts this continuous growth which represents a change that, in $C$. equitans, increases the isopod's length from about $1.7 \mathrm{~mm}$ to $8 \mathrm{~mm}$, representing an increase in surface area of $c .100$ times.

The width between the rounded extensions of the cephalon of late immature females of $C$. stroembergi n. sp. that are covered with very small cuticular denticules (Fig. 4C) are well suited to ingest the content of the eggs of the host species, H. newmani, that are reported to have a size of $0.34-0.36 \mathrm{~mm}$ (BuhlMortensen \& Mifsud, 2017). The mandibles of the late immature females of C. stroembergi n. sp. (Fig. 4C) appear to be well-adapted to forage on eggs of the host (Fig. 3F, G). Bocquet-Vedrine \& Bocquet (1972a, b) found that although no real exuviation occurs during the fast transformation from late immature to mature female, the mandibles are missing or very difficult to visualise in mature females; therefore, they are likely easily overlooked in this and other cryptoniscoid species that are egg predators.

Feeding strategies within the Cryptoniscoidea

A review of the morphologies of metamorphosing female cryptoniscoids suggests that there are three main feeding strategies that have evolved in this group: (i) piercing mouthparts and ingestion of hemolymph; (ii) internal penetration of host tissues by a specialised attachment organ; and (iii) no direct feeding attachment to the host but consumption of eggs and/or embryos likely with the use of welldeveloped mandibles as in $C$. stroembergi n. sp. Species in the first group have styliform mouthparts forming a cone that pierces the host's cuticle and either continue feeding as adults (species in the Dajidae) or feed until rupturing of the female parasite's body wall releases the larvae (species in the Hemioniscidae). The second group includes species with varied penetrating attachment structures that all serve to anchor the parasite in the host and extract nutrients, most likely through the thinner wall of the attachment process itself (species in the Cryptoniscidae, excep for Enthylacus Pérez, 1920 and Eumetor Kossmann, 1872, which probably do not belong to this family). The third group contains those species which have no feeding attachment structure in any stage of development and have either been confirmed to have, or most likely do have, mouthparts on the developing females that are found unattached to their hosts. This third group contains all species in the Cabiropidae Giard \& Bonnier, 1887 (see Boyko, 2013), except species in Gnomoniscus Giard \& Bonnier, 1895 (which probably do not belong to this family), Crinoniscidae, Podasconidae Giard \& Bonnier, 1895, and species in several genera that are currently incertae sedis: Apocumoechus Nierstrasz \& Brender à Brandis, 1931; Captioniscus Bourdon, 1972; Cumoechus Hansen, 1916; and Gorgoniscus Grygier, 1981. Several species in the Cabiropidae are known only from cryptoniscus larvae and the feeding strategies of these species are unknown. Additionally, the feeding behavior of females in several other cryptoniscoid groups is unclear. Females of species in the Entophilidae Richardson, 1903 are embedded in the visceral mass of their hosts but their mouthparts appear superficially similar to those of bopyrids and not specialised for this habitat (Boyko \& Williams, 2015). Females of species in Cyproniscidae Giard \& Bonnier, 1887 do not all have the same feeding morphology: those in Cyproniscus Kossmann, 1884 have a filamentous attachment structure (Sars, 1899) whereas those in Onisocryptus Schultz, 1977 do not (Shiino, 1942) and may be egg predators. Females of Asconiscus simplex G. O. Sars, 1899 (Asconiscidae Bonnier, 1900) appear to have no attachment structure and no mouth; their feeding behavior is unknown. However, as exemplified in species of Crinoniscus, conclusions on the lack of mandibles or specialised mouthparts should only be made if a wide developmental series is available, otherwise these structures can be easily overlooked. The morphology and feeding behavior of these cryptoniscoids should be more fully explored in order to gain a better understanding of their impacts on hosts.

Acknowledgements Open Access funding provided by Institute of Marine Research. We thank the reviewers for their work on the manuscript. Thanks to Dr Constantine Mifsud at the National Museum of Natural History, Rabat, Malta, for loan of specimens. 
Funding The research was supported by a National Science Foundation Grant (DBI-1337525) awarded to JDW (Hofstra University).

\section{Compliance with ethical standards}

Conflict of interest The authors declare that they have no conflict of interest.

Ethical approval All applicable institutional, national and international guidelines for the care and use of animals were followed.

Open Access This article is licensed under a Creative Commons Attribution 4.0 International License, which permits use, sharing, adaptation, distribution and reproduction in any medium or format, as long as you give appropriate credit to the original author(s) and the source, provide a link to the Creative Commons licence, and indicate if changes were made. The images or other third party material in this article are included in the article's Creative Commons licence, unless indicated otherwise in a credit line to the material. If material is not included in the article's Creative Commons licence and your intended use is not permitted by statutory regulation or exceeds the permitted use, you will need to obtain permission directly from the copyright holder. To view a copy of this licence, visit http://creativecommons.org/licenses/by/4.0/.

\section{References}

Blower, S., \& Roughgarden, J. (1987). Population dynamics and parasitic castration: a mathematical model. American Naturalist, 129, 730-754.

Bocquet-Védrine, [J.]. (1974). Parenté phylogénétique des isopodes cryptonisciens rangés jusqu'ici dans les familles des Liriopsidae et des Crinoniscidae. In: Arvy, L. (Ed.), Recherches biologiques contemporaines ouvrage dédié à la mémoire du Dr Manfred Gabe (1916-1973). Nancy: Imprimerie Vagner, pp. 73-78.

Bocquet-Védrine, J. (1985). Redescription de la forme cryptoniscienne du Crustacé Isopode Crinoniscus equitans Pérez. Bulletin du Muséum National d'Histoire Naturelle de Paris, $4^{e}$ série. Section A. Zoologie, biologie, et écologie animales, 7, 819-837.

Bocquet-Védrine, J. (1987). Fertilité et redescription de la larve épicaridienne du Crustacé Isopode Cryptoniscien Crinoniscus equitans Pérez. Bulletin du Muséum National d'Histoire Naturelle de Paris, $4^{e}$ série. Section A. Zoologie, biologie, et écologie animales, 9, 651-667.

Bocquet-Védrine, J., \& Bocquet, C. (1972a). Réalisation de la forme definitive chez Crinoniscus equitans Pérez, au cours de l'étape femelle du cycle de cet Isopode Cryptoniscien. Comptes Rendus Hebdomadaires des Séances de l'Académie des Sciences, 2, 2009-2011.

Bocquet-Védrine, J., \& Bocquet, C. (1972b). La ceinture d'attache de la femelle juvénile de Crinoniscus equitans Pérez (Isopode Cryptoniscien) et son importance adaptive. Comptes Rendus Hebdomadaires des Séances de l'Académie des Sciences, 275, 2235-2238.
Bocquet-Védrine, J., \& Bocquet, C. (1972c). Sur la validité des genres Leponiscus Gruvel, 1901 et Crinoniscus Pérez, 1900. (Isopodes epicarides, Cryptonisciens). Archives de Zoologie Expérimentale et Générale, 113, 395-400.

Boyko, C. B. (2013). Toward a monophyletic Cabiropidae: a review of parasitic isopods with female Cabirops-type morphology (Isopoda: Cryptoniscoidea). Proceedings of the Biological Society of Washington, 126, 103-119.

Boyko, C. B., \& Williams, J. D. (2015). A new genus for Entophilus mirebiledictu Markham \& Dworschak, 2005 (Crustacea: Isopoda: Cryptoniscoidea: Entophilidae) with remarks on morphological support for epicaridean superfamilies based on larval characters. Systematic Parasitology, 92, 13-21.

Boyko, C. B., Bruce, N. L., Hadfield, K. A., Merrin, K. L., Ota, Y., Poore, G. C. B., et al. (Eds) (2008 onwards). World Marine, Freshwater and Terrestrial Isopod Crustaceans database. Cryptoniscoidea Kossmann, 1880. World Register of Marine Species at: http://www.marinespecies. org/aphia.php? $\mathrm{p}=$ taxdetails\&id $=155729$. Accessed on 10 June 2019.

Buhl-Mortensen, L., \& Mifsud, C. (2017). A new pedunculate barnacle (Cirripedia: Heteralepadidae) from the Mediterranean with notes on reproduction. Zootaxa, 4319, 561-578.

Caullery, M. (1952). Parasitism and symbiosis. London: Sidgwick and Jackson Limited.

Caullery, M., \& Mesnil, F. (1901). Recherches sur l'Hemioniscus balani Buchholz, Epicaride parasite des Balanes. Bulletin Scientifique de la France et de la Belgique, 3, 316-362.

Fong, C. R., Moron, N. A., \& Kuris, A. M. (2017). Two's a crowd? Crowding effect in a parasitic castrator drives differences in reproductive resource allocation in single vs double infections. Parasitology, 144, 662-668.

Garm, A., \& Watling, L. (2013). The crustacean integument: setae, setules, and other ornamentation. In: Watling, L. \& Thiel, M. (Eds), The natural history of the Crustacea Vol. 1. Functional morphology and diversity. Oxford-New York: Oxford University Press, pp. 167-198.

Giard, A. (1887). Fragments biologiques. Bulletin Scientifique du Nord de la France et de la Belgique, 18, 46-53.

Gruvel, M. A. (1901). Sur un cryptoniscien parasite d'Alepas minuta Philippi. Leponiscus alepadis, n. sp. Procès-Verbaux des Séances de la Société des Sciences Physiques et Naturelles de Bordeaux, 1900-1901, 19-20.

Gruvel, M. A. (1902). Cirrhipèdes. Expéditions Scientifiques du "Travailleur" et du "Talisman" Pendant Les Années 1880, 1881, 1882, 1883, 6, 1-179.

Hesse, C. E. (1867). Observations sur des Crustacés rares ou nouveux des cotes de France (onzième article). Annales des Sciences Naturelles, Zoologie, sér. 5, 7, 123-152, pls. 2, 3.

Hosie, A. M. (2008). Four new species and a new record of Cryptoniscoidea (Crustacea: Isopoda: Hemioniscidae and Crinoniscidae) parasitizing stalked barnacles from New Zealand. Zootaxa, 1795, 1-28.

ICZN (1999). International Commission on Zoological Nomenclature. International code of zoological nomenclature (4th ed.). London: International Trust for Zoological Nomenclature. 
ICZN (2012). International Commission on Zoological Nomenclature: Amendment of articles 8, 9, 10, 21 and 78 of the International Code of Zoological Nomenclature to expand and refine methods of publication. Bulletin of Zoological Nomenclature, 69, 161-169.

Klepal, W., \& Kastner, R. (1980). Morphology and differentiation of non-sensory cuticular structures in Mysidacea, Cumacea and Tanaidacea (Crustacea, Peracarida). Zoologica Scripta, 9, 271-281.

Nielsen, S.-O., \& Strömberg, J.-O. (1973a). Morphological characters of taxonomical importance in Cryptoniscina (Isopoda Epicaridea). Sarsia, 52, 75-96.

Nielsen, S.-O., \& Strömberg, J.-O. (1973b). Surface structure of aesthetascs in Cryptoniscina (Isopoda Epicaridea). Sarsia, $52,59-74$

Shiino, S. M. (1942). Note on Cyproniscus ovalis n. sp., a new cryptoniscan parasite (Epicaridea, Isopoda) found on Cypridina hirgendorfi (sic). Annotationes Zoologicae Japonenses, 21, 82-89.

Subramoniam, T. (2017). Sexual biology and reproduction in crustaceans. Amsterdam: Academic Press.

Trilles, J.-P. (1999). Ordre des isopodes sous-ordre des épicarides (Epicaridea Latreille, 1825). In: Forest, J. (Ed). Traité de zoologie, anatomie, systématique, biologie (Pierre-P. Grassé). Tome VII, Fascicule III A, Crustacés Péracarides. Memoires de l'Institut Oceanographique, Monaco, 19, 279-352.
Watling, L. (1989). A classification of crustacean setae based on the homology concept. In: Felgenhauer, B. \& Watling, L. (Eds), Crustacean issues 6. Functional morphology of feeding and grooming in Crustacea. Rotterdam: A. A. Balkema, pp. 15-26.

Williams, J. D., \& Boyko, C. B. (2006). A new species of Tomlinsonia Turquier, 1985 (Crustacea, Cirripedia, Trypetesidae) in hermit crab shells from the Philippines, and a new parasite species of Hemioniscus Buchholz, 1866 (Crustacea, Isopoda, Hemioniscidae). Zoosystema, 28, 285-305.

Williams, J. D., \& Boyko, C. B. (2012). The global diversity of parasitic isopods associated with crustacean hosts (Isopoda: Bopyroidea and Cryptoniscoidea). PLoS ONE, 7, e35350.

Williams, J. D., Boyko, C. B., \& Madad, A. Z. (2019). Branchial parasitic isopods (Crustacea: Isopoda: Bopyridae: Pseudioninae) of hermit crabs (Crustacea: Decapoda: Paguroidea) from the western Pacific, with descriptions of a new genus and three new species. Raffles Bulletin of Zoology, $67,83-118$.

Publisher's Note Springer Nature remains neutral with regard to jurisdictional claims in published maps and institutional affiliations. 